\title{
Electrochemical Studies on the Interaction of Cadmium Ion with Kryptofix 22 in MeOH-DMF Solutions at Different Temperatures
}

\author{
E. A. Gomaa ${ }^{1, *}$, B. A. M. Al-Jahdali ${ }^{2}$ \\ ${ }^{1}$ Chemistry Department, Faculty of Science Mansoura University, Egypt \\ ${ }^{2}$ Chemistry Department, Faculty of Applied Science, Umm Al-Qura, Makkah Saudi Arabia
}

\begin{abstract}
The interaction between $\mathrm{Cd}^{2+}$ ion and Kryptofix 22 in pure $\mathrm{MeOH}$ and DMF solvents and their binary mixtures (0-100\% MeOH-DMF) at different temperatures (298.15-313.15) were measured by conductometric titrations. The conductance data in all cases were analysed using the Fuoss - Shedlovsky and Fuoss-Kraus methods to get the limiting molar conductance $\left(\Lambda_{0}\right.$ and the as sociation constant $\left(\mathrm{K}_{\mathrm{A}}\right)$ simu ltaneously. Accordingly, the co mputer progra m of Fuoss equation has been used. The conductance studies indicate the formation of 1:1 complex between the $\mathrm{Cd}^{2+}$ ion and Kryptofix 22 . From the conductivity data obtained, the values of the Walden products $\left(\Lambda_{0} \eta_{\mathrm{o}}\right)$ were also calculated. Based on the composition dependence of Walden products, the influence of the solvent composition on the solvation of the ion has been discussed. Thermodynamic parameters as well as refractive indices have been determined for $\mathrm{Cd}^{2+}$ ion in the mixed solvents at different temperatures with respect to solute-solvent interaction. This work gives a lot of data for cadmium ions which help in analysis.
\end{abstract}

Keywords Conductance, Cadmium Ion, Salvation, Association,Kryptofix-22, Thermodyna mics of Solvation

\section{Introduction}

Macrocyclic polyether's were used recently for many applications on both scientific and applied fields in chemistry. The main goal of the present investigation is to study the interaction of some divalent metal ions i.e., $\mathrm{Cd}\left(\mathrm{NO}_{3}\right)_{2}$, with Kryptofix 22 in mixed solvent of methanol $(\mathrm{MeOH})$ and dimethylformamide (DMF) at four temperatures (298.15, $303.15,308.15$ and $313.15 \mathrm{k}$ ). The interaction was studied electrochemically by the use of conductivity measurements. A lot of data on the association, dissociation and thermodynamic parameters of $\mathrm{Cd}\left(\mathrm{NO}_{3}\right)_{2}$ with Cryptand in $\mathrm{MeOH}-\mathrm{DMF}$ mixtures were determined in order to facilitate the research for biologist in selecting the necessary ligand for getting rid of toxic salts found in the environment. Macrocyclic crown ethers have some applications in biological activity, industrial production, corrosion chemistry and phase transfer catalysts.

In complexation process, macrocycle ligands compete with solvent molecules towards the metal cations in solution. As a result, variation of the solvent can produce a significant change in the apparent binding properties of these ligands. Specifically, solvents of low dielectric constants and

* Corresponding author:

nouran-esam@hotmail.com (E. A. Gomaa)

Published online at http://journal.sapub.org/scit

Copyright (C) 2012 Scientific \& Academic Publishing. All Rights Reserved solvating power lead to the greater complex stability than those tend to strong solvation of the metal cations. In addition, the selectivity for certain cations over others may be altered according to the reaction medium[1].

The experimental values of refractive indices for $\mathrm{Cd}\left(\mathrm{NO}_{3}\right)_{2}$ in mixed solvents, the excess refractive indices were calculated and their values show maximum solute-solvent interaction at about $80 \% \mathrm{MeOH}$ percentage in the mixtures. Also, the electrical conductance data the association, dissociation and thermodynamic parameters for $\mathrm{Cd}\left(\mathrm{NO}_{3}\right)_{2}$ in presence and absence of Cryptand in mixed solvents (MeOH-DMF) at the above mentioned temperatures are calculated. The association and dissociation parameters are evaluated by using Fuoss-Shedlovsky method and their values are also supported with Fuoss-Kraus method. The computer program of Fuoss equation has been used. It was concluded that the association parameters for the salt used with Cryptand are generally increased by increasing the percentage of methanol in the mixed solvents.

\section{Experimental}

Methanol (MeOH, 99.8\%), dimethylformamide (DMF, BDH, 99.8\%) were used without further purification. The purity of the solvents was ascertained by comparing experimental values of densities and viscosities with those reported in the literature. Binary mixtures were prepared by mixing known volumes of each liquid in a stopper glass 
bottle where the percentage by volume of the organic solvents varied from $0 \%$ to $100 \%$. Both of the solvents were stored in sealed containers to prevent contamination with carbon dioxide and water from the air. Cadmium nitrate $\left(\mathrm{Cd}\left(\mathrm{NO}_{3}\right)_{2}, 99 \%\right)$, was provided from $\mathrm{BDH}$. The salt was dried first in an oven at $100{ }^{\circ} \mathrm{C}$ and then stored in a desiccators over silica gel for at least $24 \mathrm{~h}$. The kryptofix 22 used was provided from Fluka and used as received without any further purification. The structure of the Kryptofix 22 is given below.

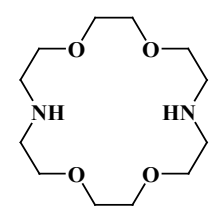

Stucture of Kryptofix $22 \quad$ 1,7,10,16-Tetraoxa-4,13-diazacyclooctadecane, $\mathrm{C}_{12} \mathrm{H}_{26} \mathrm{~N}_{2} \mathrm{O}_{4}$; M. Wt. 262.35

The viscosity $(\eta)$ of the pure solvents and binary mixtures over the entire range of composition and at the desired temperatures were measured using a calibrated U-type Ostwald viscometers immersed in a transparent glass-walled water bath having a thermal stability of $\pm 0.02 \mathrm{~K}$. Then the absolute viscosity $(\eta)$ was calculated by the following equation:

$$
\eta=\left[(\rho t) /\left(\rho_{0} t_{0}\right)\right] \eta_{0}
$$

Where $\rho_{1} \rho_{0}, t_{1} t_{0}$ and $\eta_{1} \eta_{0}$ refer to the density, flow time, and viscosity of pure solvents or binary mixtures and water respectively (Table 1$)$. The refractive indices $\left(n_{d}\right)$ of pure solvents, binary mixtures and salt solutions at the desired temperatures were measured by an Abbe refractometer which was connected with ultra thermostat of the type (mgw Lauda cs-20) with accuracy to $\pm 0.01^{\circ} \mathrm{C}$.

The dielectric constants $(\varepsilon)$ of the pure solvents at different temperatures were taken by interpolation from the data in the literature ${ }^{[1]}$, and dielectric constant for any solvent mixtures at the desired temperatures were calculated from the following equation:

$$
\varepsilon=\mathrm{x}_{\mathrm{s}(1)} \varepsilon_{(1)}+\mathrm{x}_{\mathrm{s}(2)} \varepsilon_{(2)}
$$

Where $\mathrm{x}_{\mathrm{s}(1)}$ and $\mathrm{x}_{\mathrm{S}(2)}$ are the mole fraction by weight of the first and the second organic solvents, respectively; $\varepsilon_{(1)}$ and $\varepsilon_{(2)}$ are the dielectric constants of first and the second organic solvents in the binary organic-organic mixtures respectively. The results are shown in Table (2).

Conductance measurements were carried out with a standard digital direct reading conductivity meter of the type Jenway 4310 and a conductivity cell of cell constant $0.6 \mathrm{~cm}^{-1}$. Also, some measurements were performed using a Beckman conductivity bridge model RE-18A in which the resistance of solution was determined in a jacketed g lass cell permitting circulation of water in the jacket after connecting the cell with ultra thermostat of the type (mgw Luda S-20) and kept in a thermostat maintained at the desired temperature $\pm 0.01^{\circ} \mathrm{C}$ for approximately $20 \mathrm{~min}$, and then its specific conductivity or resistance was noted .These conductivity data is accurate and technical very good, easy and novel method for cad mium ion determination.

\section{Results and Discussion}

The effects of $\mathrm{Cd}\left(\mathrm{NO}_{3}\right)_{2}$ concentrations on the molar conductance $(\Lambda)$ in the absence and presence of Kryptofix 22 were extensively studied. Straight lines were obtained in the concentration range used at the different temperatures $298.15,303.15,308.15$ and $313.15 \mathrm{~K}$.

The limiting molar conductance $\left(\Lambda_{0}\right)$ was obtained from the extrapolating the linear Onsager plots $(\Lambda)$ versus $\left(\mathrm{C}^{1 / 2}\right)$ of $\mathrm{Cd}\left(\mathrm{NO}_{3}\right)_{2}$ to zero concentration[2]. The as sociation constant $\left(\mathrm{K}_{\mathrm{A}}\right)$ could be calculated by using two different methods of calculations, involving analys is of the experimental conductivity data $(\Lambda)$ and $\left(\Lambda_{0}\right)$ by using computer program. The two methods are:

\subsection{Fuoss - Shedl ovsky Method}

In this method the values of association constant $\left(\mathrm{K}_{\mathrm{A}}\right)$ were calculated by using the sets of the following equations from (3) to (10)[2-5] :

$$
\begin{gathered}
\frac{1}{\Lambda S_{(Z)}}=\frac{1}{\Lambda_{o 0}}+\left(\frac{K_{A}}{\Lambda_{0}^{2}}\right)\left(C \cdot \Lambda \cdot \gamma_{ \pm}^{2} \cdot S_{(Z)}\right) \\
S_{(Z)}=\left(\frac{z}{2}+\left(1+\left(\frac{z}{2}\right)^{2}\right)^{\frac{1}{2}}\right)^{2} \\
\mathrm{Z}=\mathrm{S} \cdot\left(\Lambda_{0}\right)^{-3 / 2} \cdot(\mathrm{C} \Lambda)^{1 / 2} \\
\mathrm{~S}=\mathrm{a} \cdot \Lambda_{0}+\mathrm{b} \\
\mathrm{a}=8 \cdot 2 \times 10^{5}(\varepsilon \mathrm{T})^{1 / 2} \\
b=\frac{0.825}{\eta_{0}(\varepsilon T)^{1 / 2}} \\
\log \gamma_{ \pm}=\frac{-A(\alpha C)^{1 / 2}}{\left[1+B \cdot r(\alpha C)^{1 / 2}\right]} \\
\alpha=\frac{\Lambda \cdot S_{(Z)}}{\Lambda_{0}}
\end{gathered}
$$

$\mathrm{K}_{\mathrm{A}}$ is the association constant, $(\mathrm{C})$ is the concentration of metal cation at the chosen points in the relation between $(\Lambda)$ and, $\left(\gamma_{ \pm}\right)$is the mean activity coefficients estimated from the Debye Hückel limiting law as modified by Robinson and Stockes, $(\varepsilon)$ is the dielectric of the solvents, $\left(\eta_{0}\right)$ is the viscosity of the solvents, (S) is the Onsager coefficient and finally $(\alpha)$ is the degree of dissociation ${ }^{(6,7)}$ (Tables 5-8).

The physical parameters like dielectric constant $(\varepsilon)$ and viscosity $\left(\eta_{0}\right)$ and refractive indices $\left(n_{d}\right)$ for pure solvents and their mixtures at different temperatures which used in the analysis of the conductance data were taken from Tables (1)-(3).

\subsection{Fuoss-Kraus Method}

In this method the values of association constant $\left(\mathrm{K}_{\mathrm{A}}\right)$ were recalculated by applying Fuoss-Kraus method[5] of calculation depending on Eq.5. The purpose was achieved by plotting the relation of $\left(1 / \Lambda \circ . S_{(Z)}\right) v s .\left(C \Lambda \gamma_{ \pm}{ }^{2} S_{(Z)}\right)$ which gave in all cases straight lines. Figures 1-2 represent the plots of $\left(1 / \Lambda_{0} . S_{(Z)}\right)$ vs. $\left(C \Lambda \gamma_{ \pm}{ }^{2} S_{(Z)}\right)$ from the Fuoss-Kraus method for 
some metal complexes in all mixed solvents and at different temperatures.

Good agreement between the two above methods in association parameters is observed and the comparable results were tabulated in table (4). The conductance studies indicate 1:1 complex formation between the $\mathrm{Cd}^{2+}$ ion and Kryptofix. In most cases the association parameters of $\mathrm{Cd}^{2+}$ in absence and presence of Cryptand are greater in mixed solvents than in methanol. This is mainly due to the hydrogen bond strength in pure methanol which decreases in the mixed solvents and therefore facilitates the association of the cation.

It is concluded that the association constants generally increase by increasing the percentage of methanol in the mixed solvents (MeOH-DMF) due to the increase of association and decrease in the dissociation degree $(\alpha)$,d issociation constants $\left(\mathrm{K}_{\mathrm{D}}\right)$ and the decrease in ion-ion interaction (activity coefficients $\gamma$ ) on the presence of different Cryptand compounds.

The degree of dissociation is almost constant in absence of Cryptand but a very large change (decreased) is observed on adding Cryptands to enhance and increase the association. The values of $d$ issociation constant $\left(\mathrm{K}_{\mathrm{D}}\right)$, the triple ion association constant $\left(\mathrm{K}_{3}\right)[2,6,7]$ were calculated and recorded in tables (5-12).

The Walden product values $[2,8]\left(\Lambda_{0} \eta_{0}\right)$ were calculated for $\mathrm{Cd}\left(\mathrm{NO}_{3}\right)_{2}$ in mixed mixtures of MeOH-DMF. The Walden product values as calculated from the limiting molar conductance values $\left(\Lambda^{\circ}\right)$ were informative from the point of view for ion-solvent interactions. The fluidity ratios $\left(R_{X}\right)$ were also calculated and their values are given in Tables $(5-12)$.

It was observed that $R_{X}$ values were increased in the mixed solvents than in the pure $\mathrm{MeOH}$ or DMF solvents, this was an indication of selective salvation of the electrolyte. The decrease in the products of $\Lambda_{\mathrm{o}} \eta_{\mathrm{o}}$ indicates a strong solvent-solute interaction. As a result of that the solvent decrease the mobility of the ions. Activation Energies $\left(\mathrm{E}_{\mathrm{A}}\right)$, Association Enthalpies $\left(\Delta \mathrm{H}_{\mathrm{A}}\right)$ and Association Entropies $\left(\mathrm{T} \Delta \mathrm{S}_{\mathrm{A}}\right)$ of $\mathrm{Cd}\left(\mathrm{NO}_{3}\right)_{2}$ solutions mixed (MeOH-DMF) were calculated, on plotting $\left(\log \Lambda_{0}\right)$ values versus $1 / \mathrm{T}$ for $\mathrm{Cd}\left(\mathrm{NO}_{3}\right)_{2}$ in absence and presence of Cryptands straight lines were obtained. From their slopes [9] the $E_{a}$ were evaluated and represented in Tables (13-14).

It was observed that the $\mathrm{E}_{\mathrm{a}}$ values for $\mathrm{Cd}\left(\mathrm{NO}_{3}\right)_{2}$ in presence of Cryptand were greater than that in absence of Cryptand

Activation energies values are greater in the mixed sol- vents than that of pure solvents due to mainly to solvent-solvent interactions. The values of Gibbs free energies of association $\left(\Delta \mathrm{G}_{\mathrm{A}}\right)$ of $\mathrm{Cd}\left(\mathrm{NO}_{3}\right)_{2}$ in mixed MeOH-DMF solvents were calculated from the association constant values by using Eq. 11.

$$
\Delta \mathrm{G}_{\mathrm{A}}=-2.303 \mathrm{RT} \log \mathrm{K}_{\mathrm{A}}
$$

From the calculated $\Delta \mathrm{G}_{\mathrm{A}}$ values, the free energy of transfer $\left(\Delta \mathrm{G}_{\mathrm{t}}\right)$ from methanol $(\mathrm{M})$ to the mixed MeOH-DMF (s) solvents was calculated. The values of $\Delta \mathrm{G}_{\mathrm{A}}$ and $\Delta \mathrm{G}_{\mathrm{t}}$ are also, reported in Tables (5-12) and in Figures (3-4). From the plots of logarith mic as sociation constant values $\left(\log K_{A}\right)$ of $\mathrm{Cd}\left(\mathrm{NO}_{3}\right)_{2}$ in absence and presence of Kryptofix 22 against the reciprocal values of the four temperatures 298.15, 303.15, 308.15 and $313.15 \mathrm{~K}$ at the $1: 1$ (L:M)[10-12] ligand-metal ratio, straight lines were observed. From there straight relations shown in Figs. 3-4 the association enthalpies were calculated from their slopes (slope $=\Delta \mathrm{H}_{\mathrm{A}} / 2.303 \mathrm{RT}$ ). The calculated $\Delta \mathrm{H}_{\mathrm{A}}$ values are tabulated in Tables (13-14). The entropies of ass ociation $\left(\mathrm{T} \Delta \mathrm{S}_{\mathrm{A}}\right)$ of $\mathrm{Cd}\left(\mathrm{NO}_{3}\right)_{2}$ were calculated by the use of Gibbs-Helmholtz equation:

$$
\Delta \mathrm{G}_{\mathrm{A}}=\Delta \mathrm{H}_{\mathrm{A}}-\mathrm{T} \Delta \mathrm{S}_{\mathrm{A}}
$$

The calculated $\Delta \mathrm{S}_{\mathrm{A}}$ values are tabulated also in Tables (13-14). It is observed from these tables that the $\Delta \mathrm{H}_{\mathrm{A}}$ and $\Delta \mathrm{S}_{\mathrm{A}}$ values are increased with the increase of $\mathrm{MeOH}$ contents in the mixtures, which favour more association in the presence of methanol than in MeOH-DMF mixtures. Also, the enthalpies and entropies of $\mathrm{Cd}\left(\mathrm{NO}_{3}\right)_{2}$ association were increased by also adding Cryptand.

This order favours more association. From the thermodynamic parameters calculated, it was found that all these parameters are increased by increasing temperatures. This is due to the increase of interaction between $\mathrm{Cd}^{2+}$ and Cryprtand by increasing temperature. The refractive indices of the mixed solvents (MeOH-DMF) and salt solutions of $\mathrm{Cd}\left(\mathrm{NO}_{3}\right.$ )$_{2}$ in mixed solvents at different temperatures (298.15, $303.15,308.15$ and $313.15 \mathrm{~K}$ ) were measured. And from the refractive indices $\left(\mathrm{n}_{\mathrm{d}}\right)$ values, the excess refractive indices $\left(\mathrm{n}_{\mathrm{d}(\mathrm{E})}\right)$ were calculated by applying eq.(13)[5-7,10-12]:

$$
\mathrm{n}_{\mathrm{d}(\mathrm{E})}=\mathrm{n}_{\mathrm{d}(\text { mixed })}-\left[\mathrm{x}_{1} \mathrm{n}_{\mathrm{d}(1)}+\mathrm{x}_{2} \mathrm{n}_{\mathrm{d}(2)}\right]
$$

Where $\left(\mathrm{x}_{1}\right)$ and $\left(\mathrm{x}_{2}\right)$ are the mole fraction of solvent 1 $(\mathrm{MeOH})$ and solvent 2 (DMF) in their mixtures, $\left(\mathrm{n}_{\mathrm{d}}\right)$ is the measured refractive indices of the mixed solvents or the salt solution. The values of $\left(\mathrm{n}_{\mathrm{d}}\right)$ and $\left(\mathrm{n}_{\mathrm{d}(\mathrm{E})}\right)$ of MeOH-DMF mixtures and the metal are given in Table (3). The excess refractive indices show maximum values at $80 \%$ $\mathrm{MeOH}-\mathrm{DMF}$ percentages at all the used temperatures indicating maximum solute-solvent interactions at this percentage (Figure 5-6).

Table 1. The viscosities ${ }^{*}\left(\eta_{0}\right)$ of MeOH-DMF mixtures at $298.15,303.15,308.15$ and $313.15 \mathrm{~K}$

\begin{tabular}{|c|c|c|c|c|c|}
\hline Vol.\% of & \multirow{2}{*}{$\mathrm{X}_{\mathrm{MeOH}}$} & \multicolumn{4}{|c|}{ MeOH-DMF mixtures } \\
\cline { 3 - 6 } & & $298.15 \mathrm{~K}$ & $303.15 \mathrm{~K}$ & $308.15 \mathrm{~K}$ & $313.15 \mathrm{~K}$ \\
\hline 0 & 0.0000 & 0.8488 & 0.7588 & 0.7045 & 0.6566 \\
\hline 20 & 0.3222 & 0.7698 & 0.7041 & 0.6494 & 0.6033 \\
\hline 40 & 0.5590 & 0.7400 & 0.6734 & 0.6233 & 0.5738 \\
\hline 60 & 0.7404 & 0.6392 & 0.6015 & 0.5526 & 0.5258 \\
\hline 80 & 0.8838 & 0.6610 & 0.56997 & 0.5302 & 0.5133 \\
\hline 100 & 1.0000 & 0.5759 & 0.5461 & 0.5309 & 0.4871 \\
\hline
\end{tabular}

* $\left(\eta_{0}\right)$ in poise 
Table 2. The dielectric constants $(\varepsilon)$ of MeOH-DMF mixtures at 298.15, 303.15, 308.15 and $313.15 \mathrm{~K}$

\begin{tabular}{|c|c|c|c|c|c|}
\hline \multirow{2}{*}{$\begin{array}{c}\text { Vol.\% of } \\
\mathrm{MeOH}\end{array}$} & \multirow{2}{*}{$\mathrm{X}_{\mathrm{MeOH}}$} & \multicolumn{4}{|c|}{ MeOH-DMF } \\
\cline { 3 - 6 } & & $298.15 \mathrm{~K}$ & $303.15 \mathrm{~K}$ & $308.15 \mathrm{~K}$ & $313.15 \mathrm{~K}$ \\
\hline 0 & 0.0000 & 38.6000 & 37.6000 & 36.2000 & 34.7000 \\
\hline 20 & 0.3222 & 36.6990 & 35.7320 & 34.3641 & 32.9013 \\
\hline 40 & 0.559 & 35.3019 & 34.3586 & 33.0143 & 31.5758 \\
\hline 60 & 0.7404 & 34.2316 & 33.3063 & 31.9802 & 30.5588 \\
\hline 80 & 0.8838 & 33.3856 & 32.4743 & 31.1626 & 29.7535 \\
\hline 100 & 1.0000 & 32.7000 & 31.8000 & 30.5000 & 29.1000 \\
\hline
\end{tabular}

Table 3. The refract ive indices $\left(\mathrm{n}_{\mathrm{d}}\right)$, the excess refractive indices $\left(\mathrm{n}_{\mathrm{d}(\mathrm{E})}\right)$ and the molecular dipole polarizability ${ }^{*}(\alpha)$ of $\mathrm{Cd}\left(\mathrm{NO}_{3}\right)_{2}$ in MeOH-DMF mixtures at $298.15,303.15,308.15$ and $313.15 \mathrm{~K}$

\begin{tabular}{|c|c|c|c|c|c|c|c|c|c|c|c|c|}
\hline \multirow{2}{*}{$\begin{array}{l}\text { Vol.\% of } \\
\text { MeOH }\end{array}$} & \multicolumn{4}{|c|}{$\mathrm{n}_{\mathrm{d}}$} & \multicolumn{4}{|c|}{$\mathrm{n}_{\mathrm{d}(\mathrm{E})} \times 10^{-2}$} & \multicolumn{4}{|c|}{$\alpha \times 10^{-24}$} \\
\hline & $298.15 \mathrm{~K}$ & $303.15 \mathrm{~K}$ & $308.15 \mathrm{~K}$ & $313.15 \mathrm{~K}$ & $298.15 \mathrm{~K}$ & $303.15 \mathrm{~K}$ & $308.15 \mathrm{~K}$ & $313.15 \mathrm{~K}$ & $298.15 \mathrm{~K}$ & $303.15 \mathrm{~K}$ & $308.15 \mathrm{~K}$ & $313.15 \mathrm{~K}$ \\
\hline 0 & 1.4280 & 1.4263 & 1.4248 & 1.4240 & 00.00 & 00.00 & 00.00 & 00.00 & 0.1020 & 0.1016 & 0.1011 & 0.1013 \\
\hline 20 & 1.4112 & 1.4118 & 1.4110 & 1.4083 & 1.55 & 1.89 & 1.89 & 1.56 & 0.0984 & 0.0988 & 0.0984 & 0.0978 \\
\hline 40 & 1.3940 & 1.3925 & 1.3920 & 1.3910 & 2.20 & 2.24 & 2.33 & 2.20 & 0.0948 & 0.0945 & 0.0944 & 0.0942 \\
\hline 60 & 1.3783 & 1.3745 & 1.3730 & 1.3725 & 2.07 & 2.64 & 2.23 & 2.17 & 0.0906 & 0.0914 & 0.0903 & 0.0902 \\
\hline 80 & 1.3575 & 1.3515 & 1.3500 & 1.3480 & 1.21 & 2.01 & 1.35 & 1.16 & 0.0856 & 0.0869 & 0.0853 & 0.0848 \\
\hline 100 & 1.3278 & 1.3258 & 1.3250 & 1.3248 & 00.00 & 00.00 & 00.00 & 00.00 & 0.0803 & 0.0799 & 0.0797 & 0.0797 \\
\hline
\end{tabular}

$\mathrm{R}$ in $\left(\mathrm{mol} . \mathrm{cm}^{-3}\right)$ and $\alpha\left(\mathrm{cm}^{-3}\right)$

Table 4. Fuoss-Kraus association constant $\left[\log \mathrm{K}_{\mathrm{A}}(\mathrm{F}-\mathrm{K})\right]$ in comparison with Fuoss-Shedlovsky data $\left[\log \mathrm{K}_{\mathrm{A}}(\mathrm{F}-\mathrm{Sh})\right]$ for Cd( $\left.\mathrm{NO}_{3}\right)_{2}$ in presence of Kry-22 in mixed MeOH-DMF mixtures at 298.15, 303.15, 308.15 and 313.15K

\begin{tabular}{|c|c|c|c|c|c|c|c|c|}
\hline \multirow{2}{*}{$\mathrm{Vol} \%$ of $\mathrm{MeOH}$} & \multicolumn{2}{|c|}{$298.15 \mathrm{~K}$} & \multicolumn{2}{c|}{$303.15 \mathrm{~K}$} & \multicolumn{2}{c|}{308.15} & \multicolumn{2}{c|}{$313.15 \mathrm{~K}$} \\
\cline { 2 - 9 } & $\begin{array}{c}\text { Log } \mathrm{K}_{\mathrm{A}} \\
(\mathrm{F}-\mathrm{K})\end{array}$ & $\begin{array}{c}\text { Log } \mathrm{K}_{\mathrm{A}} \\
(\mathrm{F}-\mathrm{Sh})\end{array}$ & $\begin{array}{c}\text { Log } \mathrm{K}_{\mathrm{A}} \\
(\mathrm{F}-\mathrm{K})\end{array}$ & $\begin{array}{c}\text { Log } \mathrm{K}_{\mathrm{A}} \\
(\mathrm{F}-\mathrm{Sh})\end{array}$ & $\begin{array}{c}\text { Log } \mathrm{K}_{\mathrm{A}} \\
(\mathrm{F}-\mathrm{K})\end{array}$ & $\begin{array}{c}\log _{\mathrm{A}} \\
(\mathrm{F}-\mathrm{Sh})\end{array}$ & $\begin{array}{c}\text { Log K }_{\mathrm{A}} \\
(\mathrm{F}-\mathrm{K})\end{array}$ & $\begin{array}{c}\text { Log } \mathrm{K}_{\mathrm{A}} \\
(\mathrm{F}-\mathrm{Sh})\end{array}$ \\
\hline $0 \%$ & 3.170 & 4.14 & 3.203 & 4.44 & 4.71 & 4.56 & 3.17 & 3.82 \\
\hline $20 \%$ & 4.71 & 4.18 & 6.09 & 4.41 & 3.42 & 4.55 & 3.47 & 4.20 \\
\hline $40 \%$ & 4.17 & 3.32 & 4.34 & 4.91 & 6.06 & 4.29 & 5.67 & 4.35 \\
\hline $60 \%$ & 4.37 & 3.44 & 4.05 & 4.96 & 5.43 & 4.18 & 6.22 & 4.29 \\
\hline $80 \%$ & 4.35 & 3.42 & 3.60 & 4.90 & 5.01 & 4.12 & 7.09 & 4.28 \\
\hline $100 \%$ & 3.69 & 3.88 & 3.66 & 3.89 & 3.30 & 4.86 & 3.78 & 3.65 \\
\hline
\end{tabular}

Table 5. The values of molar conductance ${ }^{*}(\Lambda)$, limiting molar conductance ${ }^{*}\left(\Lambda_{0}\right)$, degree of dissociation $(\alpha)$, act ivity coefficient $\left(\gamma_{ \pm}\right)$, association constant* ${ }_{*}^{*}$ $\left(\mathrm{K}_{\mathrm{A}}\right)$, dissociation constant ${ }^{*}\left(\mathrm{~K}_{\mathrm{D}}\right)$, triple ion association constant ${ }^{*}\left(-\mathrm{K}_{3}\right)$, Gibbs free energy of association $\left(\Delta \mathrm{G}_{\mathrm{A}}\right)$, transfer Gibbs free energy of association $\left(\Delta \mathrm{G}_{\mathrm{t}}\right)$, Walden product $\left(\Lambda_{0} \eta_{0}\right)$ and the fluidity ratio $\left(\mathrm{R}_{\mathrm{x}}\right)$ of $\mathrm{Cd}\left(\mathrm{NO}_{3}\right)_{2}$ in MeOH-DMF mixt ures at $298.15 \mathrm{~K}$

\begin{tabular}{|c|c|c|c|c|c|c|c|c|c|c|c|c|}
\hline $\begin{array}{c}\text { Vol.\% of } \\
\text { MeOH }\end{array}$ & C & $\Lambda$ & $\Lambda_{0}$ & $\alpha$ & $\gamma_{ \pm}$ & $\mathbf{K}_{\mathbf{A}}$ & $\mathbf{K}_{\mathbf{D}}$ & $\mathbf{K}_{\mathbf{3}}$ & $\Delta \mathbf{G}_{\mathbf{A}}$ & $\Delta \mathbf{G}_{\mathbf{t}}$ & $\Lambda_{0} \eta_{0}$ & $\mathbf{R}_{\mathbf{x}}$ \\
\hline 0 & $8 \times 10^{-5}$ & 99.5 & 112 & 0.8996 & 0.9435 & $1.72 \times 10^{3}$ & $5.81 \times 10^{4}$ & $1.07 \times 10^{-3}$ & -18.463 & 1.7669 & 0.9507 & 1.1634 \\
\hline 20 & $8 \times 10^{-5}$ & 83 & 94 & 0.8966 & 0.9393 & $1.80 \times 10^{3}$ & $5.55 \times 10^{4}$ & $1.08 \times 10^{-3}$ & -18.575 & 1.6555 & 0.7236 & 0.8856 \\
\hline 40 & $8 \times 10^{-5}$ & 119.8 & 133 & 0.9130 & 0.9352 & $1.47 \times 10^{3}$ & $6.78 \times 10^{4}$ & $0.99 \times 10^{-3}$ & -18.079 & 2.1513 & 0.9842 & 1.2045 \\
\hline 60 & $8 \times 10^{-5}$ & 127.5 & 148.15 & 0.8726 & 0.9338 & $2.37 \times 10^{3}$ & $4.22 \times 10^{-4}$ & $1.26 \times 10^{-3}$ & -19.255 & 0.9756 & 0.9470 & 1.1589 \\
\hline 80 & $8 \times 10^{-5}$ & 122.8 & 136 & 0.9165 & 0.9297 & $1.42 \times 10^{3}$ & $7.04 \times 10^{-4}$ & $0.97 \times 10^{-3}$ & -17.986 & 2.2443 & 0.8990 & 1.1002 \\
\hline 100 & $8 \times 10^{-5}$ & 116 & 141.88 & 0.8301 & 0.9309 & $3.51 \times 10^{3}$ & $2.85 \times 10^{-4}$ & $1.54 \times 10^{-3}$ & -20.230 & 0.0000 & 0.8171 & 1.0000 \\
\hline
\end{tabular}

${ }^{*} \mathrm{C}$ in $(\mathrm{mol} / \mathrm{l}), \Lambda$ and $\Lambda_{0}$ in $\left(\Omega^{-1} \cdot \mathrm{cm}^{2} \cdot \mathrm{mol}^{-1}\right), \mathrm{K}_{\mathrm{A}}$ and $-\mathrm{K}_{3}$ in $(\mathrm{mol} / \mathrm{l}), \mathrm{K}_{\mathrm{D}}$ in $\left(\mathrm{mol}^{-1} . \mathrm{L}\right)$ and $\Delta \mathrm{G}_{\mathrm{A}}$ and $\Delta \mathrm{G}_{\mathrm{t}}$ in $(\mathrm{KJ} / \mathrm{mol})$.

Table 6. The values of molar conductance ${ }^{*}(\Lambda)$, limiting molar conductance ${ }^{*}\left(\Lambda_{0}\right)$, degree of dissociation $(\alpha)$, act ivity coefficient $\left(\gamma_{ \pm}\right)$, association constant ${ }^{*}$ $\left(\mathrm{K}_{\mathrm{A}}\right)$, dissociation constant ${ }^{*}\left(\mathrm{~K}_{\mathrm{D}}\right)$, triple ion association constant ${ }^{*}\left(-\mathrm{K}_{3}\right)$, Gibbs free energy of association ${ }^{*}\left(\Delta \mathrm{G}_{\mathrm{A}}\right)$, transfer Gibbs free energy of association ${ }^{*}$ $\left(\Delta \mathrm{G}_{\mathrm{t}}\right)$, Walden product $\left(\Lambda_{0} \eta_{0}\right)$ and the fluidity rat io $\left(\mathrm{R}_{\mathrm{x}}\right)$ of $\mathrm{Cd}\left(\mathrm{NO}_{3}\right)_{2}$ in MeOH-DMF mixtures at $303.15 \mathrm{~K}$

\begin{tabular}{|c|c|c|c|c|c|c|c|c|c|c|c|c|}
\hline $\begin{array}{c}\text { Vol.\% } \\
\text { of } \\
\text { МеОН }\end{array}$ & C & $\Lambda$ & $\Lambda_{0}$ & $\alpha$ & $\gamma_{ \pm}$ & $\mathbf{K}_{\mathbf{A}}$ & $\mathbf{K}_{\mathbf{D}}$ & $\mathbf{K}_{3}$ & $\Delta \mathbf{G}_{\mathbf{A}}$ & $\Delta \mathbf{G}_{\mathbf{t}}$ & $\Lambda_{0} \eta_{0}$ & $\mathbf{R}_{\mathbf{x}}$ \\
\hline 0 & $8 \times 10^{-5}$ & 108 & 122 & 0.8966 & 0.9428 & $1.79 \times 10^{3}$ & $5.60 \times 10^{-4}$ & $1.09 \times 10^{-3}$ & -18.866 & -0.2420 & 0.9257 & 1.1152 \\
\hline 20 & $8 \times 10^{-5}$ & 90.5 & 103 & 0.8922 & 0.9386 & $1.90 \times 10^{3}$ & $5.27 \times 10^{-4}$ & $1.12 \times 10^{-3}$ & -19.018 & -0.3943 & 0.7252 & 0.8737 \\
\hline 40 & $8 \times 10^{-5}$ & 132 & 134.61 & 0.9952 & 0.9315 & $0.069 \times 10^{3}$ & $145.58 \times 10^{4}$ & $0.19 \times 10^{-3}$ & -10.657 & 7.9670 & 0.9065 & 1.0921 \\
\hline 60 & $8 \times 10^{-5}$ & 139 & 156 & 0.9039 & 0.9316 & $1.67 \times 10^{3}$ & $5.97 \times 10^{4}$ & $1.06 \times 10^{-3}$ & -18.703 & -0.0793 & 0.9383 & 1.1304 \\
\hline 80 & $8 \times 10^{-5}$ & 128 & 144 & 0.9030 & 0.9290 & $1.70 \times 10^{3}$ & $5.87 \times 10^{-4}$ & $1.07 \times 10^{-3}$ & -18.745 & -0.1211 & 0.8208 & 0.9888 \\
\hline 100 & $8 \times 10^{-5}$ & 135.7 & 152 & 0.9071 & 0.9267 & $1.62 \times 10^{3}$ & $6.16 \times 10^{-4}$ & $1.04 \times 10^{-3}$ & -18.624 & 0.0000 & 0.8301 & 1.0000 \\
\hline
\end{tabular}

${ }^{*} \mathrm{C}$ in $(\mathrm{mol} / \mathrm{l}), \Lambda$ and $\Lambda_{0}$ in $\left(\Omega^{-1} \cdot \mathrm{cm}^{2} \cdot \mathrm{mol}^{-1}\right), \mathrm{K}_{\mathrm{A}}$ and $-\mathrm{K}_{3}$ in $(\mathrm{mol} / \mathrm{l}), \mathrm{K}_{\mathrm{D}}$ in $\left(\mathrm{mol}^{-1} . \mathrm{L}\right)$ and $\Delta \mathrm{G}_{\mathrm{A}}$ and $\Delta \mathrm{G}_{\mathrm{t}}$ in $(\mathrm{KJ} / \mathrm{mol})$. 
Table 7. The values of molar conduct ance ${ }^{*}(\Lambda)$, limiting molar ${ }_{*}$ conduct ance ${ }^{*}\left(\Lambda_{0}\right)$, degree of dissociation $(\alpha)$, act ivity coefficient $\left(\gamma_{ \pm}\right)$, association const ant* ${ }_{*}^{*}$ $\left(\mathrm{K}_{\mathrm{A}}\right)$, dissociation constant ${ }^{*}\left(\mathrm{~K}_{\mathrm{D}}\right)$, triple ion association constant ${ }^{*}\left(-\mathrm{K}_{3}\right)$, Gibbs free energy of association $\left(\Delta \mathrm{G}_{\mathrm{A}}\right)$, transfer Gibbs free energy of association $\left(\Delta \mathrm{G}_{\mathrm{t}}\right)$, Walden product $\left(\Lambda_{0} \eta_{0}\right)$ and the fluidity ratio $\left(\mathrm{R}_{\mathrm{x}}\right)$ of $\mathrm{Cd}\left(\mathrm{NO}_{3}\right)_{2}$ in MeOH-DMF mixt ures at $308.15 \mathrm{~K}$

\begin{tabular}{|c|c|c|c|c|c|c|c|c|c|c|c|c|}
\hline $\begin{array}{c}\text { Vol.\% } \\
\text { of } \\
\text { МeOH } \\
\end{array}$ & C & $\Lambda$ & $\Lambda_{0}$ & $\alpha$ & $\gamma_{ \pm}$ & $\mathbf{K}_{\mathbf{A}}$ & $\mathbf{K}_{\mathbf{D}}$ & $\mathbf{K}_{3}$ & $\Delta \mathbf{G}_{\mathbf{A}}$ & $\Delta \mathbf{G}_{t}$ & $\Lambda_{0} \eta_{0}$ & $\mathbf{R}_{\mathbf{x}}$ \\
\hline 0 & $8 \times 10^{-5}$ & 107.5 & 121 & 0.9007 & 0.9409 & $1.71 \times 10^{3}$ & $5.86 \times 10^{-4}$ & $1.06 \times 10^{-3}$ & -19.063 & -0.1135 & 0.8524 & 1.0849 \\
\hline 20 & $8 \times 10^{-5}$ & 88.5 & 101 & 0.8909 & 0.9366 & $1.93 \times 10^{3}$ & $5.17 \times 10^{-4}$ & $1.13 \times 10^{-3}$ & -19.381 & -0.4319 & 0.6559 & 0.8348 \\
\hline 40 & $8 \times 10^{-5}$ & 135 & 138.06 & 0.9932 & 0.9292 & $0.099 \times 10^{3}$ & $101.13 \times 10^{4}$ & $0.23 \times 10^{-3}$ & -11.766 & 7.1834 & 0.8605 & 1.0952 \\
\hline 60 & $8 \times 10^{-5}$ & 141 & 157 & 0.9120 & 0.9288 & $1.52 \times 10^{3}$ & $6.60 \times 10^{-4}$ & $1.01 \times 10^{-3}$ & -18.756 & 0.1931 & 0.8676 & 1.1042 \\
\hline 80 & $8 \times 10^{-5}$ & 128 & 144 & 0.9039 & 0.9264 & $1.69 \times 10^{3}$ & $5.91 \times 10^{-4}$ & $1.06 \times 10^{-3}$ & -19.039 & -0.0896 & 0.7635 & 0.9717 \\
\hline 100 & $8 \times 10^{-5}$ & 132 & 148 & 0.9070 & 0.9240 & $1.63 \times 10^{3}$ & $6.12 \times 10^{-4}$ & $1.04 \times 10^{-3}$ & -18.949 & 0.0000 & 0.7857 & 1.0000 \\
\hline
\end{tabular}

${ }^{*} \mathrm{C}$ in $(\mathrm{mol} / \mathrm{l}), \Lambda$ and $\Lambda_{0}$ in $\left(\Omega^{-1} \cdot \mathrm{cm}^{2} \cdot \mathrm{mol}^{-1}\right), \mathrm{K}_{\mathrm{A}}$ and $-\mathrm{K}_{3}$ in $(\mathrm{mol} / \mathrm{l}), \mathrm{K}_{\mathrm{D}}$ in $\left(\mathrm{mol}^{-1} . \mathrm{L}\right)$ and $\Delta \mathrm{G}_{\mathrm{A}}$ and $\Delta \mathrm{G}_{\mathrm{t}}$ in $(\mathrm{KJ} / \mathrm{mol})$.

Table 8. The values of molar conductance ${ }^{*}(\Lambda)$, limiting molar conductance ${ }^{*}\left(\Lambda_{0}\right)$, degree of dissociation $(\alpha)$, activity coefficient $\left(\gamma_{ \pm}\right)$,association constant $^{*}\left(\mathrm{~K}_{\mathrm{A}}\right)$, dissociation constant ${ }^{*}\left(\mathrm{~K}_{\mathrm{D}}\right)$, triple ion association constant ${ }^{*}\left(-\mathrm{K}_{3}\right)$, Gibbs free energy of association $\left(\Delta \mathrm{G}_{\mathrm{A}}\right)$, transfer $\mathrm{Gib}$ bS free energy of association $\left(\Delta \mathrm{G}_{\mathrm{t}}\right)$, Walden product $\left(\Lambda_{0} \eta_{0}\right)$ and the fluidity ratio $\left(\mathrm{R}_{\mathrm{x}}\right)$ of $\mathrm{Cd}\left(\mathrm{NO}_{3}\right)_{2}$ in MeOH-DMF mixt ures at $313.15 \mathrm{~K}$

\begin{tabular}{|c|c|c|c|c|c|c|c|c|c|c|c|c|}
\hline $\begin{array}{c}\text { Vol.\% of } \\
\text { MeOH }\end{array}$ & $\mathbf{C}$ & $\boldsymbol{\Lambda}$ & $\boldsymbol{\Lambda}_{\mathbf{0}}$ & $\boldsymbol{\alpha}$ & $\boldsymbol{\gamma}_{ \pm}$ & $\mathbf{K}_{\mathbf{A}}$ & $\mathbf{K}_{\mathbf{D}}$ & $\mathbf{K}_{\mathbf{3}}$ & $\Delta \mathbf{G}_{\mathbf{A}}$ & $\boldsymbol{\Delta G}_{\mathbf{t}}$ & $\boldsymbol{\Lambda}_{\mathbf{0}} \boldsymbol{\eta}_{\mathbf{0}}$ & $\mathbf{R}_{\mathbf{x}}$ \\
\hline 0 & $8 \times 10^{-5}$ & 109 & 130 & 0.8499 & 0.9403 & $2.90 \times 10^{3}$ & $3.45 \times 10^{-4}$ & $1.40 \times 10^{-3}$ & -20.751 & -0.2325 & 0.8536 & 1.1529 \\
\hline 20 & $8 \times 10^{-5}$ & 91 & 109 & 0.8488 & 0.9355 & $2.96 \times 10^{3}$ & $3.38 \times 10^{-4}$ & $1.41 \times 10^{-3}$ & -20.803 & -0.2848 & 0.6576 & 0.8882 \\
\hline 40 & $8 \times 10^{-5}$ & 119 & 140 & 0.8633 & 0.9310 & $2.61 \times 10^{3}$ & $3.83 \times 10^{4}$ & $1.33 \times 10^{-3}$ & -20.479 & 0.0387 & 0.8033 & 1.0850 \\
\hline 60 & $8 \times 10^{-5}$ & 142 & 166.5 & 0.8660 & 0.9276 & $2.56 \times 10^{3}$ & $3.90 \times 10^{-4}$ & $1.32 \times 10^{-3}$ & -20.430 & 0.0881 & 0.8755 & 1.1824 \\
\hline 80 & $8 \times 10^{-5}$ & 126 & 149 & 0.8600 & 0.9250 & $2.73 \times 10^{3}$ & $3.66 \times 10^{4}$ & $1.36 \times 10^{-3}$ & -20.596 & -0.0774 & 0.7648 & 1.0330 \\
\hline 100 & $8 \times 10^{-5}$ & 129 & 152 & 0.8637 & 0.9224 & $2.65 \times 10^{3}$ & $3.77 \times 10^{-4}$ & $1.34 \times 10^{-3}$ & -20.518 & 0.0000 & 0.7404 & 1.0000 \\
\hline
\end{tabular}

${ }^{*} \mathrm{C}$ in $(\mathrm{mol} / \mathrm{l}), \Lambda$ and $\Lambda_{0}$ in $\left(\Omega^{-1} \cdot \mathrm{cm}^{2} \cdot \mathrm{mol}^{-1}\right), \mathrm{K}_{\mathrm{A}}$ and $-\mathrm{K}_{3}$ in $(\mathrm{mol} / \mathrm{l}), \mathrm{K}_{\mathrm{D}}$ in $\left(\mathrm{mol}^{-1} . \mathrm{L}\right)$ and $\Delta \mathrm{G}_{\mathrm{A}}$ and $\Delta \mathrm{G}_{\mathrm{t}}$ in $(\mathrm{KJ} / \mathrm{mol})$.

Table 9. The values of molar conduct ance* $(\Lambda)$, limiting molar conductance ${ }^{*}\left(\Lambda_{0}\right)$, degree of dissociation $(\alpha)$, act ivity coefficient $\left(\gamma_{ \pm}\right)$, association constant* ${ }_{*}^{*}$ $\left(\mathrm{K}_{\mathrm{A}}\right)$, dissociation constant ${ }^{*}\left(\mathrm{~K}_{\mathrm{D}}\right)$, triple ion association constant ${ }^{*}\left(-\mathrm{K}_{3}\right)$, Gibbs free energy of association ${ }^{*}\left(\Delta \mathrm{G}_{\mathrm{A}}\right)$, transfer Gibbs free energy of association ${ }^{*}$ $\left(\Delta \mathrm{G}_{\mathrm{A}}\right)$, Walden product $\left(\Lambda_{0} \eta_{0}\right)$ and the fluidity ratio $\left(\mathrm{R}_{\mathrm{x}}\right)$ of $\mathrm{Cd}\left(\mathrm{NO}_{3}\right)_{2}$ in the presence of Kryptofix-22 in MeOH-DMF mixtures at $298.15 \mathrm{~K}$

\begin{tabular}{|c|c|c|c|c|c|c|c|c|c|c|c|c|}
\hline $\begin{array}{c}\text { Vol.\% of } \\
\text { MeOH } \\
\end{array}$ & C & $\Lambda$ & $\Lambda_{0}$ & $\alpha$ & $\gamma_{ \pm}$ & $\mathbf{K}_{\mathbf{A}}$ & $\mathbf{K}_{\mathbf{D}}$ & $\mathbf{K}_{3}$ & $\Delta \mathbf{G}_{\mathbf{A}}$ & $\Delta \mathbf{G}_{\mathbf{t}}$ & $\Lambda_{0} \eta_{0}$ & $\mathbf{R}_{\mathbf{x}}$ \\
\hline 0 & $8 \times 10^{-5}$ & 340 & 555.68 & 0.6154 & 0.9531 & $13.80 \times 10^{3}$ & $0.73 \times 10^{-4}$ & $3.14 \times 10^{-3}$ & -23.621 & -1.4707 & 4.7166 & 0.8759 \\
\hline 20 & $8 \times 10^{-5}$ & 360 & 605 & 0.5987 & 0.9501 & $15.31 \times 10^{3}$ & $0.65 \times 10^{-4}$ & $3.31 \times 10^{-3}$ & -23.879 & -1.7280 & 4.6573 & 0.8649 \\
\hline 40 & $8 \times 10^{-5}$ & 41.4 & 48 & 0.8846 & 0.9362 & $2.08 \times 10^{3}$ & $4.81 \times 10^{-4}$ & $1.13 \times 10^{-3}$ & -18.930 & 3.2207 & 0.3552 & 0.0660 \\
\hline 60 & $8 \times 10^{-5}$ & 67.6 & 80.5 & 0.8564 & 0.9344 & $2.77 \times 10^{3}$ & $3.61 \times 10^{-4}$ & $1.34 \times 10^{-3}$ & -19.641 & 2.5097 & 0.5146 & 0.0956 \\
\hline 80 & $8 \times 10^{-5}$ & 62 & 73.5 & 0.8613 & 0.9317 & $2.66 \times 10^{3}$ & $3.76 \times 10^{-4}$ & $1.31 \times 10^{-3}$ & -19.540 & 2.6109 & 0.4858 & 0.0902 \\
\hline 100 & $8 \times 10^{-5}$ & 668 & 935 & 0.7199 & 0.9355 & $7.62 \times 10^{3}$ & $1.31 \times 10^{-4}$ & $2.33 \times 10^{-3}$ & -22.151 & 0.0000 & 5.3847 & 1.0000 \\
\hline
\end{tabular}

${ }^{*} \mathrm{C}$ in $(\mathrm{mol} / \mathrm{l}), \Lambda$ and $\Lambda_{0}$ in $\left(\Omega^{-1} \cdot \mathrm{cm}^{2} \cdot \mathrm{mol}^{-1}\right), \mathrm{K}_{\mathrm{A}}$ and $-\mathrm{K}_{3}$ in $(\mathrm{mol} / \mathrm{l}), \mathrm{K}_{\mathrm{D}}$ in $\left(\mathrm{mol}^{-1} . \mathrm{L}\right)$ and $\Delta \mathrm{G}_{\mathrm{A}}$ and $\Delta \mathrm{G}_{\mathrm{t}}$ in $(\mathrm{KJ} / \mathrm{mol})$.

Table 10. The values of molar conduct ance* $(\Lambda)$, limit ing molar conductance ${ }_{*}^{*}\left(\Lambda_{0}\right)$, degree of dissociation $(\alpha)$, activity coefficient $\left(\gamma_{ \pm}\right)$, associat ion constant* $\left(\mathrm{K}_{\mathrm{A}}\right)$, dissociation constant ${ }^{*}\left(\mathrm{~K}_{\mathrm{D}}\right)$, triple ion association constant ${ }^{*}\left(-\mathrm{K}_{3}\right)$, Gibbs free energy of association ${ }^{*}\left(\Delta \mathrm{G}_{\mathrm{A}}\right)$, transfer Gibbs free energy of association ${ }^{*}$ $\left(\Delta \mathrm{G}_{\mathrm{A}}\right)$, Walden product $\left(\Lambda_{0} \eta_{0}\right)$ and the fluidity rat io $\left(\mathrm{R}_{\mathrm{x}}\right)$ of $\mathrm{Cd}\left(\mathrm{NO}_{3}\right)_{2}$ in the presence of Kryptofix-22 in MeOH-DMF mixtures at $303.15 \mathrm{~K}$

\begin{tabular}{|c|c|c|c|c|c|c|c|c|c|c|c|c|}
\hline $\begin{array}{c}\text { Vol.\% of } \\
\text { МeOH } \\
\end{array}$ & C & $\Lambda$ & $\Lambda_{0}$ & $\alpha$ & $\gamma_{ \pm}$ & $\mathbf{K}_{\mathbf{A}}$ & $\mathbf{K}_{\mathbf{D}}$ & $\mathbf{K}_{3}$ & $\Delta \mathbf{G}_{\mathbf{A}}$ & $\Delta \mathbf{G}_{t}$ & $\Lambda_{0} \eta_{0}$ & $\mathbf{R}_{\mathbf{x}}$ \\
\hline 0 & $8 \times 10^{-5}$ & 310 & 630 & 0.4947 & 0.9572 & $27.83 \times 10^{3}$ & $0.360 \times 10^{-4}$ & $4.47 \times 10^{-3}$ & -25.785 & -3.2321 & 4.7804 & 0.9313 \\
\hline 20 & $8 \times 10^{-5}$ & 330 & 650 & 0.5106 & 0.9532 & $25.50 \times 10^{3}$ & $0.392 \times 10^{-4}$ & $4.28 \times 10^{-3}$ & -25.565 & -3.0124 & 4.5767 & 0.8916 \\
\hline 40 & $8 \times 10^{-5}$ & 46 & 140 & 0.3313 & 0.9599 & $81.61 \times 10^{3}$ & $0.122 \times 10^{-4}$ & $7.54 \times 10^{-3}$ & -28.496 & -5.9431 & 0.9428 & 0.1837 \\
\hline 60 & $8 \times 10^{-5}$ & 60 & 190 & 0.3182 & 0.9588 & $90.40 \times 10^{3}$ & $0.111 \times 10^{-4}$ & $7.99 \times 10^{-3}$ & -28.754 & -6.2010 & 1.1429 & 0.2226 \\
\hline 80 & $8 \times 10^{-5}$ & 80 & 240 & 0.3358 & 0.9561 & $79.52 \times 10^{3}$ & $0.126 \times 10^{-4}$ & $7.51 \times 10^{-3}$ & -28.431 & -5.8778 & 1.3680 & 0.2665 \\
\hline 100 & $8 \times 10^{-5}$ & 670 & 940 & 0.7184 & 0.9345 & $7.72 \times 10^{3}$ & $1.30 \times 10^{-4}$ & $2.35 \times 10^{-3}$ & -22.553 & 0.0000 & 5.1333 & 1.0000 \\
\hline
\end{tabular}

\footnotetext{
${ }^{*} \mathrm{C}$ in $(\mathrm{mol} / \mathrm{l}), \Lambda$ and $\Lambda_{0}$ in $\left(\Omega^{-1} . \mathrm{cm}^{2} \cdot \mathrm{mol}^{-1}\right), \mathrm{K}_{\mathrm{A}}$ and $-\mathrm{K}_{3}$ in $(\mathrm{mol} / \mathrm{l}), \mathrm{K}_{\mathrm{D}}$ in $\left(\mathrm{mol}^{-1} . \mathrm{L}\right)$ and $\Delta \mathrm{G}_{\mathrm{A}}$ and $\Delta \mathrm{G}_{\mathrm{t}}$ in $(\mathrm{KJ} / \mathrm{mol})$.
} 
Table 11. The values of molar conductance ${ }^{*}(\Lambda)$, limiting molar conductance ${ }^{*}\left(\Lambda_{0}\right)$, degree of dissociation $(\alpha)$, activity coefficient $\left(\gamma_{ \pm}\right)$, association constant ${ }_{*}^{*}$ $\left(\mathrm{K}_{\mathrm{A}}\right)$, dissociation constant ${ }^{*}\left(\mathrm{~K}_{\mathrm{D}}\right)$, triple ion association constant ${ }^{*}\left(-\mathrm{K}_{3}\right)$, Gibbs free energy of association ${ }^{*}\left(\Delta \mathrm{G}_{\mathrm{A}}\right)$, transfer Gibbs free energy of association ${ }^{*}$ $\left(\Delta \mathrm{G}_{\mathrm{A}}\right)$, Walden product $\left(\Lambda_{0} \eta_{0}\right)$ and the fluidity ratio $\left(\mathrm{R}_{\mathrm{x}}\right)$ of $\mathrm{Cd}\left(\mathrm{NO}_{3}\right)_{2}$ in the presence of Kryptofix-22 in MeOH-DMF mixtures at $308.15 \mathrm{~K}$

\begin{tabular}{|c|c|c|c|c|c|c|c|c|c|c|c|c|}
\hline $\begin{array}{c}\text { Vol.\%of } \\
\text { MeOH }\end{array}$ & $\mathbf{C}$ & $\boldsymbol{\Lambda}$ & $\boldsymbol{\Lambda}_{\mathbf{0}}$ & $\boldsymbol{\alpha}$ & $\boldsymbol{\gamma}_{ \pm}$ & $\mathbf{K}_{\mathbf{A}}$ & $\mathbf{K}_{\mathbf{D}}$ & $\mathbf{K}_{\mathbf{3}}$ & $\boldsymbol{\Delta G}_{\mathbf{A}}$ & $\boldsymbol{\Delta G}_{\mathbf{t}}$ & $\boldsymbol{\Lambda}_{\mathbf{0}} \boldsymbol{\eta}_{\mathbf{0}}$ & $\mathbf{R}_{\mathbf{x}}$ \\
\hline 0 & $8 \times 10^{-5}$ & 270 & 600 & 0.4524 & 0.9577 & $36.01 \times 10^{3}$ & $0.278 \times 10^{-4}$ & $5.09 \times 10^{-3}$ & -26.870 & 1.7656 & 4.2270 & 0.7511 \\
\hline 20 & $8 \times 10^{-5}$ & 300 & 660 & 0.4571 & 0.9541 & $35.23 \times 10^{3}$ & $0.284 \times 10^{-4}$ & $5.03 \times 10^{-3}$ & -26.814 & 1.8221 & 4.2860 & 0.7616 \\
\hline 40 & $8 \times 10^{-5}$ & 45 & 82 & 0.5576 & 0.9464 & $19.61 \times 10^{3}$ & $0.509 \times 10^{-4}$ & $3.63 \times 10^{-3}$ & -25.314 & 3.3225 & 0.5111 & 0.0908 \\
\hline 60 & $8 \times 10^{-5}$ & 71 & 119 & 0.6054 & 0.9416 & $14.99 \times 10^{3}$ & $0.667 \times 10^{-4}$ & $3.21 \times 10^{-3}$ & -24.626 & 4.0103 & 0.6576 & 0.1169 \\
\hline 80 & $8 \times 10^{-5}$ & 65.5 & 106 & 0.6284 & 0.9383 & $13.20 \times 10^{3}$ & $0.758 \times 10^{-4}$ & $3.00 \times 10^{-3}$ & -24.300 & 4.3361 & 0.5620 & 0.0999 \\
\hline 100 & $8 \times 10^{-5}$ & 370 & 1060 & 0.3510 & 0.9520 & $71.75 \times 10^{3}$ & $0.139 \times 10^{-4}$ & $7.20 \times 10^{-3}$ & -28.636 & 0.0000 & 5.6275 & 1.0000 \\
\hline
\end{tabular}

${ }^{*} \mathrm{C}$ in $(\mathrm{mol} / \mathrm{l}), \Lambda$ and $\Lambda_{0}$ in $\left(\Omega^{-1} \cdot \mathrm{cm}^{2} \cdot \mathrm{mol}^{-1}\right), \mathrm{K}_{\mathrm{A}}$ and $-\mathrm{K}_{3}$ in $(\mathrm{mol} / \mathrm{l}), \mathrm{K}_{\mathrm{D}}$ in $\left(\mathrm{mol}^{-1} \cdot \mathrm{L}\right)$ and $\Delta \mathrm{G}_{\mathrm{A}}$ and $\Delta \mathrm{G}_{\mathrm{t}}$ in $(\mathrm{KJ} / \mathrm{mol})$.

Table 12. The values of molar conductance ${ }^{*}(\Lambda)$, limitingmolar conduct ance ${ }^{*}\left(\Lambda_{0}\right)$, degree of dissociation $(\alpha)$, activity coefficient $\left(\gamma_{ \pm}\right)$, association constant ${ }_{*}^{*}$ $\left(\mathrm{K}_{\mathrm{A}}\right)$, dissociation constant ${ }^{*}\left(\mathrm{~K}_{\mathrm{D}}\right)$, triple ion association constant ${ }^{*}\left(-\mathrm{K}_{3}\right)$, Gibbs free energy of association $\left(\Delta \mathrm{G}_{\mathrm{A}}\right)$, transfer Gibbs free energy of association $\left(\Delta \mathrm{G}_{\mathrm{A}}\right)$, Walden product $\left(\Lambda_{0} \eta_{0}\right)$ and the fluidity ratio $\left(\mathrm{R}_{\mathrm{x}}\right)$ of $\mathrm{Cd}\left(\mathrm{NO}_{3}\right)_{2}$ in the presence of Kryptofix-22 in MeOH-DMF mixtures at $313.15 \mathrm{~K}$

\begin{tabular}{|c|c|c|c|c|c|c|c|c|c|c|c|c|}
\hline $\begin{array}{c}\text { Vol.\%of } \\
\text { МeOH }\end{array}$ & C & $\Lambda$ & $\Lambda_{0}$ & $\alpha$ & $\gamma_{ \pm}$ & $\mathbf{K}_{\mathbf{A}}$ & $\mathbf{K}_{\mathbf{D}}$ & $\mathbf{K}_{3}$ & $\Delta \mathbf{G}_{\mathbf{A}}$ & $\Delta \mathbf{G}_{\mathbf{t}}$ & $\Lambda_{0} \eta_{0}$ & $\mathbf{R}_{\mathbf{x}}$ \\
\hline 0 & $8 \times 10^{-5}$ & 460 & 625.7 & 0.7404 & 0.9442 & $6.56 \times 10^{3}$ & $1.525 \times 10^{-4}$ & $2.157 \times 10^{-3}$ & -22.874 & -0.9840 & 4.1082 & 0.9694 \\
\hline 20 & $8 \times 10^{-5}$ & 420 & 712.7 & 0.5933 & 0.9458 & $15.95 \times 10^{3}$ & $0.627 \times 10^{-4}$ & $3.379 \times 10^{-3}$ & -25.187 & -3.2969 & 4.2997 & 1.0146 \\
\hline 40 & $8 \times 10^{-5}$ & 46 & 87 & 0.5374 & 0.9452 & $22.13 \times 10^{3}$ & $0.452 \times 10^{-4}$ & $3.868 \times 10^{-3}$ & -26.039 & -4.1500 & 0.4992 & 0.1178 \\
\hline 60 & $8 \times 10^{-5}$ & 72.5 & 131 & 0.5613 & 0.9413 & $19.41 \times 10^{3}$ & $0.515 \times 10^{-4}$ & $3.663 \times 10^{-3}$ & -25.698 & -3.8080 & 0.6888 & 0.1625 \\
\hline 80 & $8 \times 10^{-5}$ & 67 & 120 & 0.5670 & 0.9386 & $18.87 \times 10^{3}$ & $0.530 \times 10^{-4}$ & $3.605 \times 10^{-3}$ & -25.625 & -3.7350 & 0.6160 & 0.1454 \\
\hline 100 & $8 \times 10^{-5}$ & 690 & 870 & 0.8004 & 0.9251 & $4.49 \times 10^{3}$ & $2.23 \times 10^{-4}$ & $1.783 \times 10^{-3}$ & -21.889 & 0.0000 & 4.2378 & 1.0000 \\
\hline
\end{tabular}

${ }^{*} \mathrm{C}$ in $(\mathrm{mol} / \mathrm{l}), \Lambda$ and $\Lambda_{0}$ in $\left(\Omega^{-1} \cdot \mathrm{cm}^{2} \cdot \mathrm{mol}^{-1}\right), \mathrm{K}_{\mathrm{A}}$ and $-\mathrm{K}_{3}$ in $(\mathrm{mol} / \mathrm{l}), \mathrm{K}_{\mathrm{D}}$ in $\left(\mathrm{mol}^{-1} . \mathrm{L}\right)$ and $\Delta \mathrm{G}_{\mathrm{A}}$ and $\Delta \mathrm{G}_{\mathrm{t}}$ in $(\mathrm{KJ} / \mathrm{mol})$.

Table 13. The activation energy ${ }^{*}\left(\mathrm{E}_{\mathrm{a}}\right)$, the enthalpy* $\left(\Delta \mathrm{H}_{\mathrm{A}}\right)$ andthe entropy*$\left(\Delta \mathrm{S}_{\mathrm{A}}\right)$ changes of associat ion of $\left.\mathrm{Cd}_{(\mathrm{NO}}\right)_{2}$ in MeOH-DMF mixt ures at 298.15 , $303.15,308.15,313.15 \mathrm{~K}$

\begin{tabular}{|c|c|c|c|cccc|}
\hline \multirow{2}{*}{$\begin{array}{c}\text { Vol.\% of first } \\
\text { organic sol vent }\end{array}$} & \multirow{2}{*}{$\begin{array}{c}\mathbf{X}_{\mathbf{S} \text { (MeOH) }} \\
\text { by weight }\end{array}$} & $\mathbf{E}_{\mathbf{A}}$ & $\boldsymbol{\Delta} \mathbf{H}_{\mathbf{A}}$ & \multicolumn{3}{|c|}{$\boldsymbol{\Delta}$} \\
\cline { 5 - 7 } & & & $289.15 \mathrm{~K}$ & $303.15 \mathrm{~K}$ & $308.15 \mathrm{~K}$ & $313.15 \mathrm{~K}$ \\
\hline $\boldsymbol{0}$ & 0.000 & 6.8143 & -28.4680 & -0.0336 & -0.0317 & -0.0305 & -0.0247 \\
$\mathbf{2 0}$ & 0.322 & 6.5929 & -5.4732 & 0.0440 & 0.0447 & 0.0452 & 0.0490 \\
$\mathbf{4 0}$ & 0.559 & 2.7777 & -29.6149 & -0.0387 & -0.0626 & -0.0580 & -0.0292 \\
$\mathbf{6 0}$ & 0.740 & 7.5235 & -33.3505 & -0.0473 & -0.0483 & -0.0474 & -0.0413 \\
$\mathbf{8 0}$ & 0.884 & 4.2597 & -34.3193 & -0.0548 & -0.0514 & -0.0496 & -0.0438 \\
$\mathbf{1 0 0}$ & 1.000 & 2.8129 & -38.5662 & -0.0615 & -0.0658 & -0.0637 & -0.0577 \\
\hline
\end{tabular}

${ }^{*} \mathrm{E}_{\mathrm{a}}, \Delta \mathrm{G}_{\mathrm{A}}, \Delta \mathrm{H}_{\mathrm{A}}$ in $(\mathrm{KJ} / \mathrm{mol})$ and $\Delta \mathrm{S}_{\mathrm{A}}$ in $(\mathrm{KJ} / \mathrm{K} \cdot \mathrm{mol})$.

Table 14. The enthalpy ${ }^{*}\left(\Delta \mathrm{H}_{\mathrm{A}}\right)$ and the entropy ${ }^{*}\left(\Delta \mathrm{S}_{\mathrm{A}}\right)$ changes of association of $\left.\mathrm{Cd}_{(\mathrm{NO}}\right)_{2}$ in the presence of Kryptofix-22 in MeOH-DMF mixtures at $298.15,303.15,308.15,313.15 \mathrm{~K}$

\begin{tabular}{|c|c|c|c|c|c|c|c|}
\hline \multirow{2}{*}{$\begin{array}{c}\text { Vol.\% of first or- } \\
\text { ganic solvent }\end{array}$} & \multirow{2}{*}{$\begin{array}{c}\mathrm{XS}_{\mathrm{S} \text { (MeOH) }} \\
\text { by weight }\end{array}$} & \multirow{2}{*}{$\mathbf{E}_{\mathrm{A}}$} & \multirow{2}{*}{$\Delta \mathbf{H}_{\mathbf{A}}$} & \multicolumn{4}{|c|}{$\Delta \mathbf{S}_{\mathrm{A}}$} \\
\hline & & & & $289.15 \mathrm{~K}$ & $303.15 \mathrm{~K}$ & $308.15 \mathrm{~K}$ & $313.15 \mathrm{~K}$ \\
\hline 0 & 0.000 & 4.807 & -73.3910 & -0.1670 & -0.1571 & -0.1510 & -0.1614 \\
\hline 20 & 0.322 & 7.858 & -63.6738 & -0.1335 & 0.1258 & -0.1197 & -0.1230 \\
\hline 40 & 0.559 & 32.309 & -129.8578 & -0.3722 & -0.3345 & -0.3394 & -0.3317 \\
\hline 60 & 0.740 & -25.895 & -105.0316 & -0.2865 & -0.2517 & -0.2611 & -0.2535 \\
\hline 80 & 0.884 & 25.747 & -104.5779 & -0.2854 & -0.2513 & -0.2606 & -0.2522 \\
\hline 100 & 1.000 & 9.528 & -170.1760 & -0.4967 & -0.4872 & -0.4595 & -0.4738 \\
\hline
\end{tabular}

${ }^{*} \mathrm{E}_{\mathrm{a}}, \Delta \mathrm{H}_{\mathrm{A}}$ in $(\mathrm{KJ} / \mathrm{mol})$ and $\Delta \mathrm{S}_{\mathrm{A}}$ in $(\mathrm{KJ} / \mathrm{K} \cdot \mathrm{mol})$. 

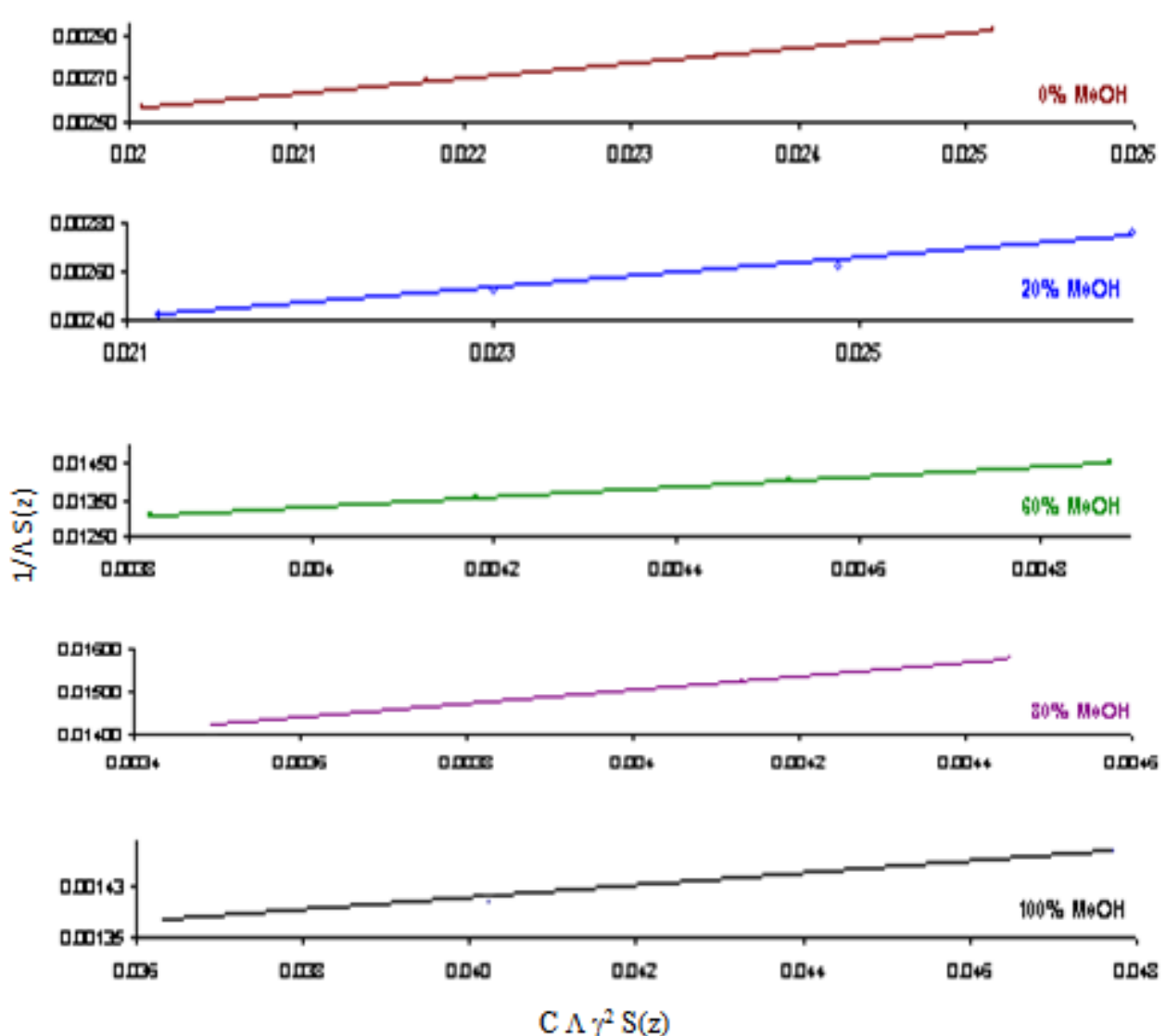

(a)
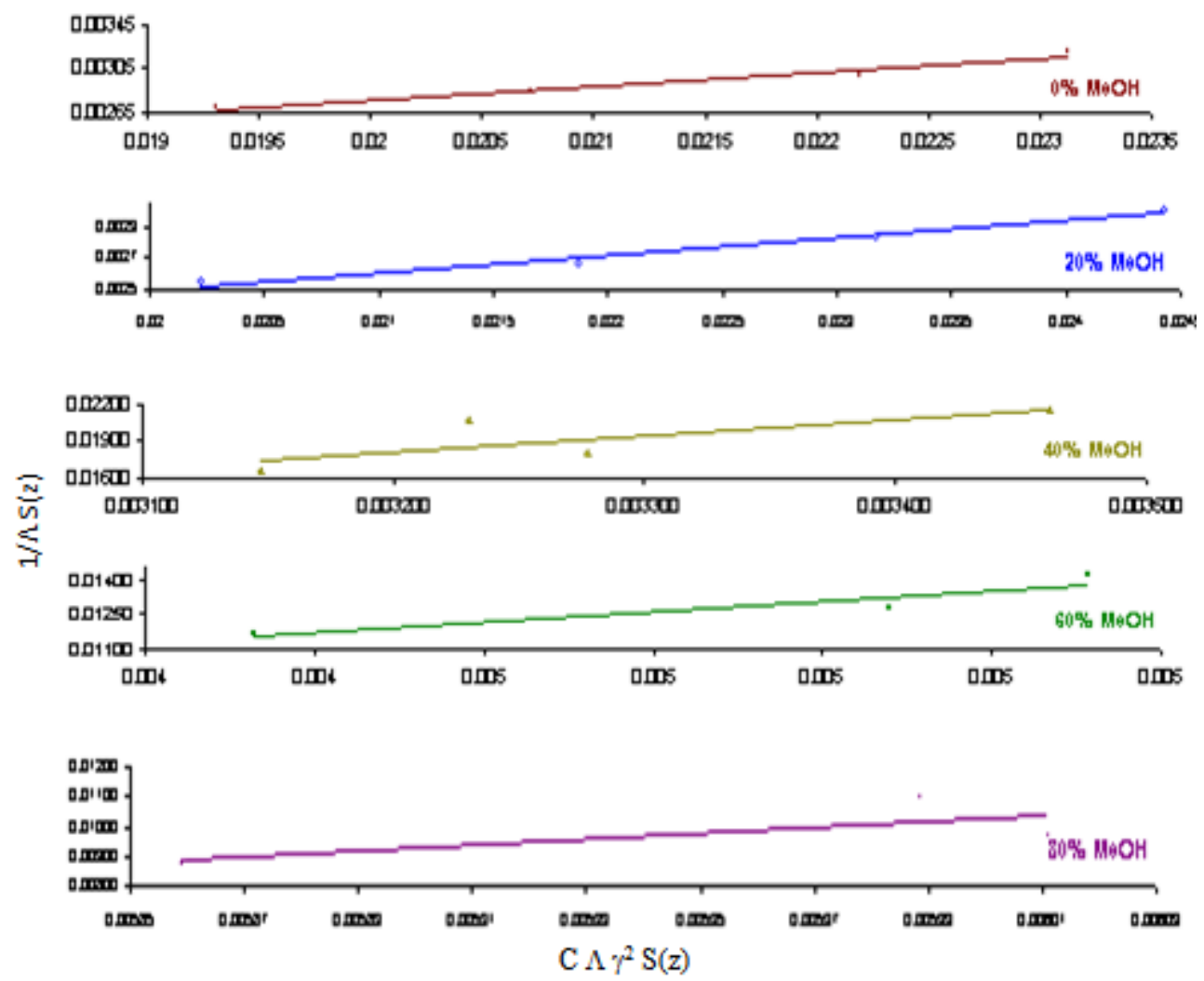

(b)

Figure 1. Fuoss-Kraus plots of $\mathrm{Cd}\left(\mathrm{NO}_{3}\right)_{2}$ in presence of $\mathrm{Kry}-22$ in MeOH-DMF mixtures at (a) $298.15 \mathrm{~K}$ and (b) $303.15 \mathrm{~K}$ 

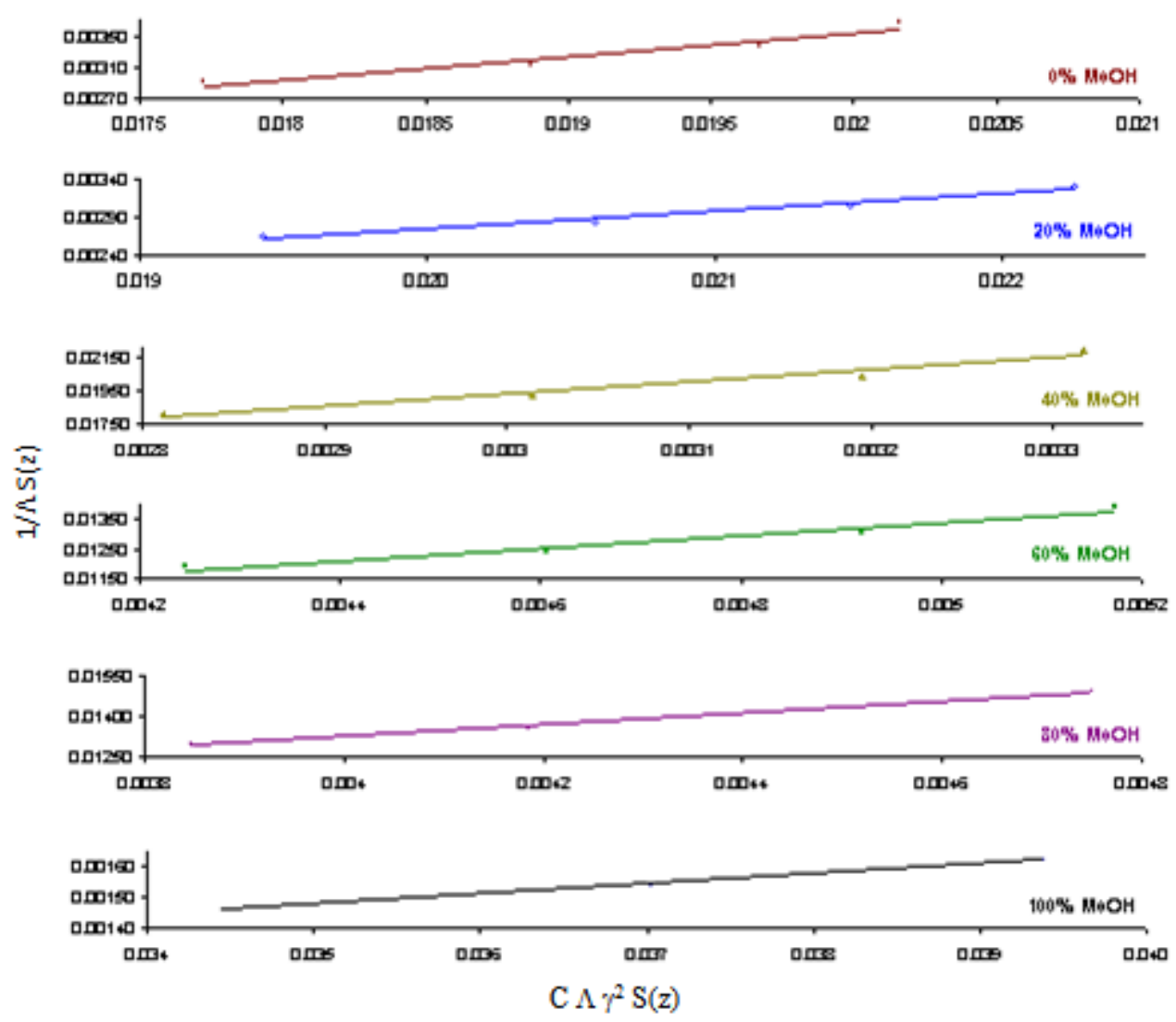

(a)
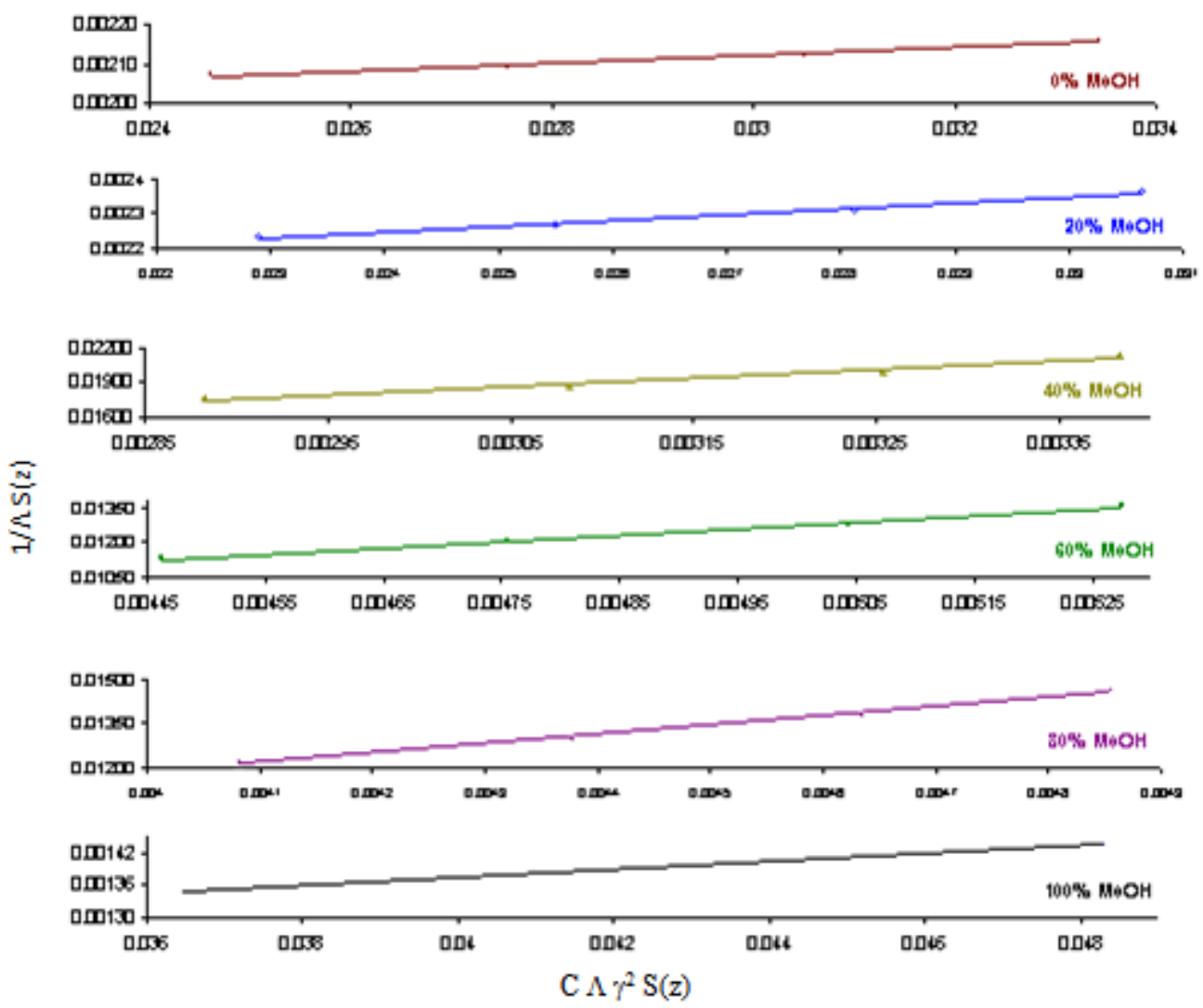

(b)

Figure 2. Fuoss-Kraus plots of $\mathrm{Cd}\left(\mathrm{NO}_{3}\right)_{2}$ in presence of $\mathrm{Kry}-22$ in MeOH-DMF mixtures at (c) $308.15 \mathrm{~K}$ and (d) $313.15 \mathrm{~K}$ 

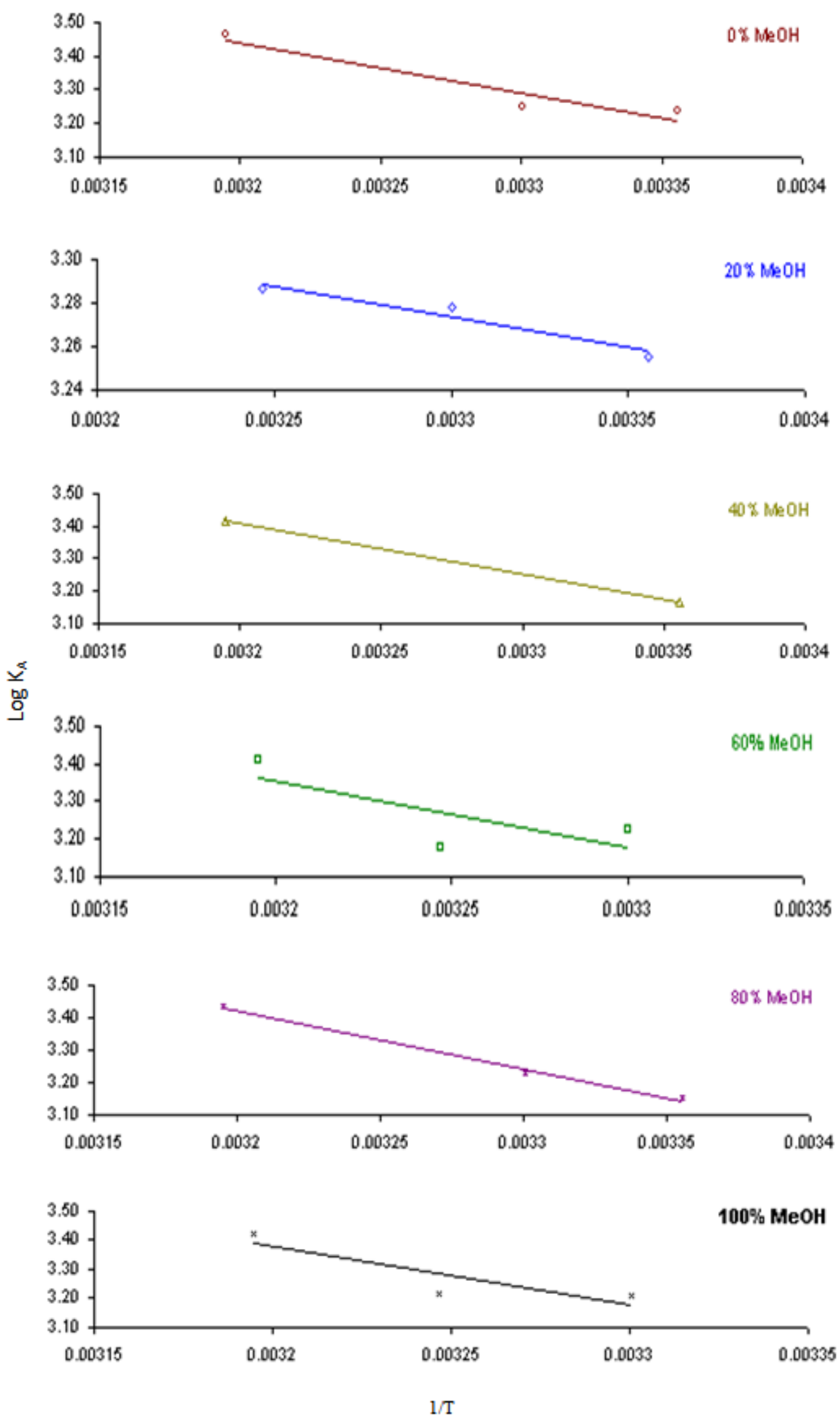

Figure 3. Variation of $\log \mathrm{K}_{\mathrm{A}}$ with $1 / \mathrm{T}$ in mixed MeOH-DMF solvents for $\mathrm{Cd}\left(\mathrm{NO}_{3}\right)_{2}$ 

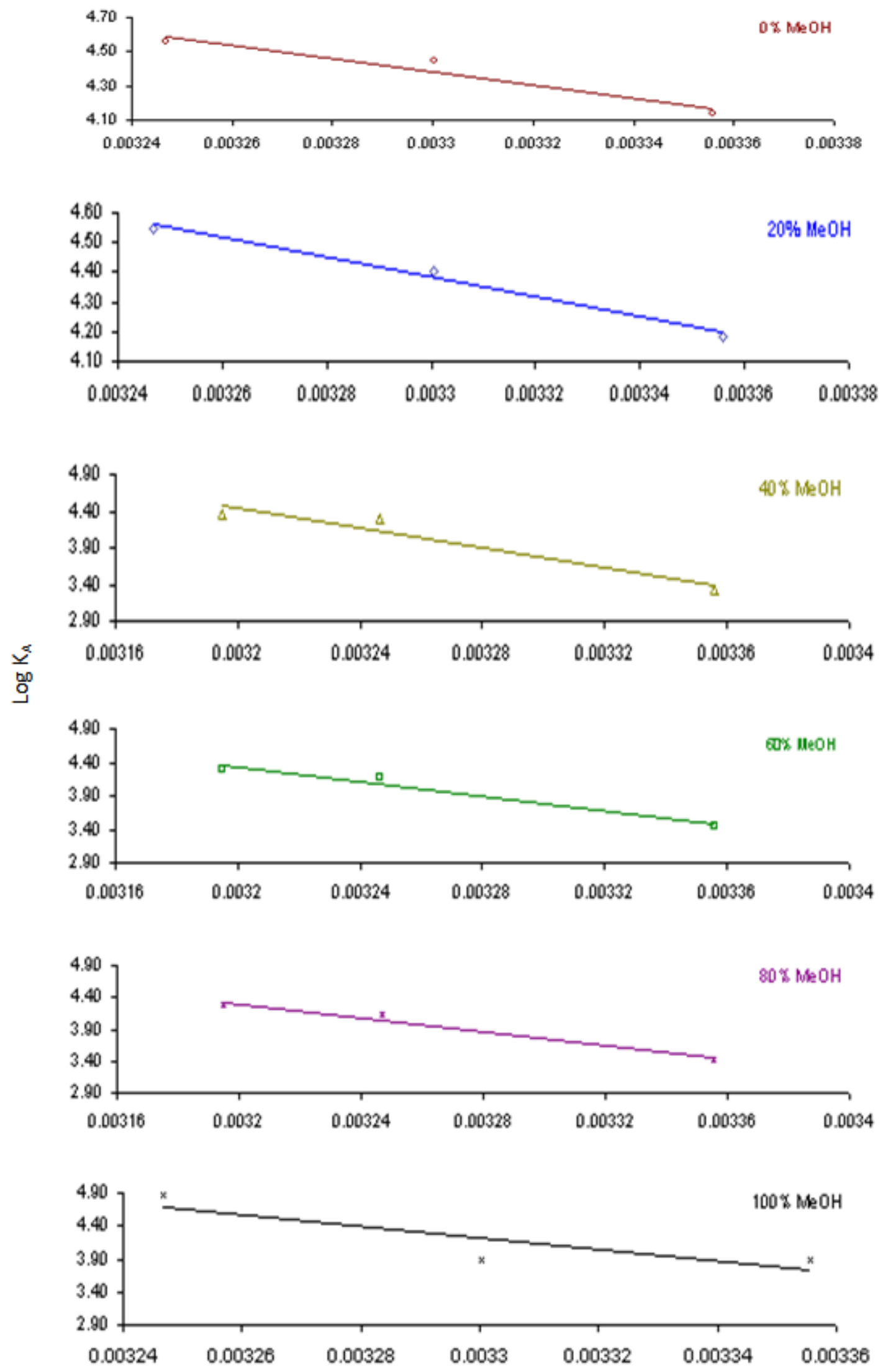

$1 / \mathrm{T}$

Figure 4. Variation of $\mathrm{Log} \mathrm{K}_{\mathrm{A}}$ with $1 / \mathrm{T}$ in mixed $\mathrm{MeOH}-\mathrm{DMF}$ solvents for $\mathrm{Cd}\left(\mathrm{NO}_{3}\right)_{2}$ in presence of $\mathrm{Kry}-22$ 


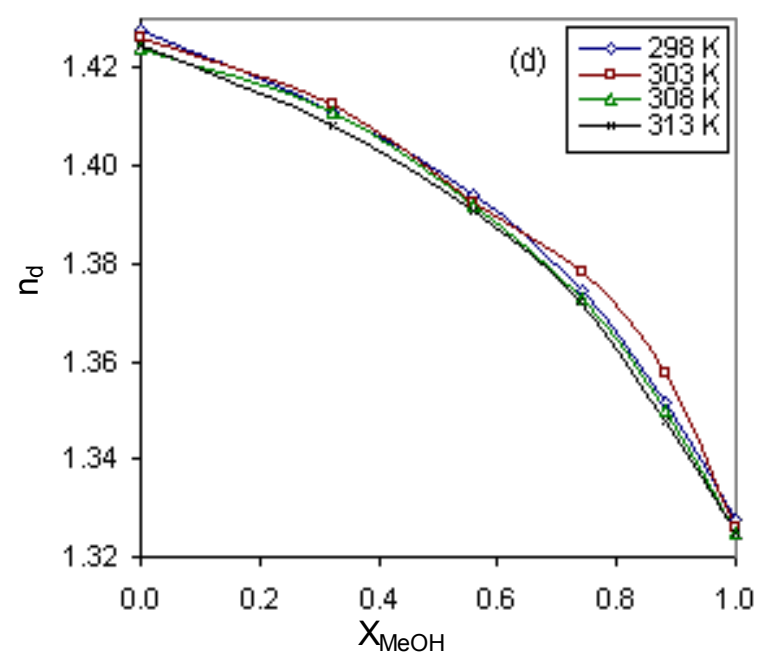

Figure 5. Variation of the refractive indices (nd) with the mole fraction (XMeOH) by weight of $\mathrm{MeOH}$ for $\mathrm{Cd}\left(\mathrm{NO}_{3}\right)_{2}$ at $298,303,308,313 \mathrm{~K}$ in mixed MeOH-DMF solvents

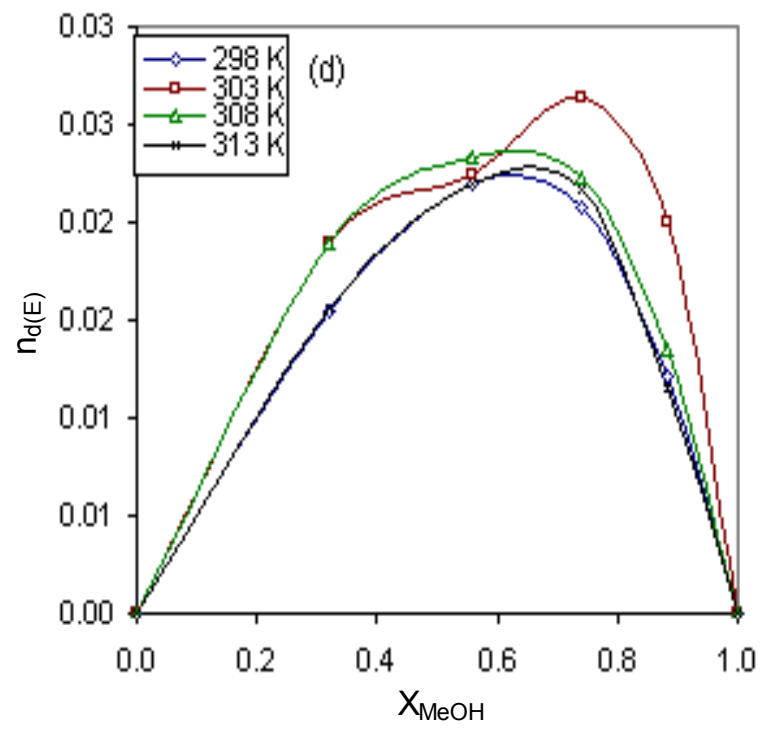

Figure 6. Variation of the excess refractive indices (nd(E)) with the mole fraction $\left(\mathrm{X}_{\mathrm{MeOH}}\right)$ by weight of $\mathrm{MeOH}$ for $\mathrm{Cd}\left(\mathrm{NO}_{3}\right)_{2}$ at $298,303,308,313 \mathrm{~K}$ in mixed MeOH-DMF solvents

\section{REFERENCES}

[1] E.A., Gomaa, Thermochimica Acta, 142 (1989) 19 and E. A, Gomaa , , Croatica Chemica Acta, 62 (1989) 475.

[2] E.A.,Gomaa, M.A. ,Hafez, and M.N.H., Moussa, Bull. Soc. Chim. Fr., 3 (1986)361.

[3] E.A.Gomaa, Thermochim. Acta, 99, (1988)128.

[4] M.A., Hafez, E. A. ,Gomaa, and M.N.H., Moussa, First conference of Chem. Faculty of science, Mansoura university, 24-26 Sep. (1986).

[5] A. K., Covington and T.Dickinson,; "Physical Chemistry of Organic Solvent Systems", Plenum Press, London, (1973).

[6] T. Shedlovsky, and R.L Kay, J. Phys., Chem.60(1956)151.

[7] R.M. ,Fuoss, andF., Accascina, Electrolytic conductance, Interscience, New York (1959).

[8] R.A., Robinson, and R, H. ,Stokes ; "Electroyte Solutions", Wiley, P.463 (1968) New York.

[9] P.,Walden; Z.Phys. chem., 78(1912)257.

[10] E. A., Gomaa, Thermochimica. Acta, 152(1989)71.

[11] E. A. Gomaa, Thermochimica. Acta, 156(1989)91.

[12] A.A., EL-Khouly, E.A. ,Gomaa, and S., EL-Ashry, second conf. in Basic science, Assiut University, Assiut 2000. 